Acta vet. scand. $1986,27,598-608$.

From the Department of Microbiology and Immunology, Norwegian College of Veterinary Medicine, Oslo and the State Veterinary Laboratory for Northern Norway, Harstad, Norway.

\title{
CORYNEBACTERIUM PSEUDOTUBERCULOSIS INFECTION IN GOATS III.
}

\author{
THE INFLUENCE OF AGE
}

\author{
By \\ Gudmund Holstad
}

HOLSTAD, G.: Corynebacterium pseudotuberculosis infection in goats III. The influence of age. Acta vet. scand. 1986, 27, 598-608. Serological examinations for Corynebacterium pseudotuberculosis infection were carried out in 14 known positive herds and in 1 herd that had been recently established through purchase of animals from different herds. Serum samples were collected sequentially on up to 4 occasions from animals during their first year of life. In most herds, these animals were examined clinically for superficial swellings once or twice during the same period.

The adult goats in 8 infected herds were examined both clinically and serologically. Age distribution was similar in each of these herds. All serum samples were examined for antibodies against Corynebacterium pseudotuberculosis in both the bacterial agglutination test (BAT) and the hemolysis inhibition test (HIT).

The proportion of kids which were seropositive in both tests decreased to zero at 4 months of age. At the age of 11-12 months, the proportion of seropositive animals was about $50 \%$ in the BAT and $30 \%$ in the HIT.

When examined when housed for the winter at the age of about 8 months (mean age), the prevalence of animals with superficial swellings was $7 \%$. At the age of about 1 year (mean age), $29 \%$ of the examined animals had such lesions. In the recently established herd, only a few of the yearlings were seropositive.

Titre values in BAT and HIT increased until 6 years of age. Antibody titre values were significantly lower in yearlings than in older goats in both tests, $\mathrm{P}<0.005$. No significant difference in the proportion of goats with superficial swellings was seen at the different ages.

antibodies; superficial swellings; kids; adult a $\mathrm{n}$ im a ls.

Caseous lymphadenitis is a chronic disease caused by Corynebacterium pseudotuberculosis. The disease seems to be rare in kids. Ashfaq \& Campbell (1979) found that superficial abscesses 
were most frequent in goats 3-4 years of age while such lesions seldom were demonstrated in kids. Lund et al (1982) examined animals in a naturally infected herd for antibodies against C. pseudotuberculosis and found that most animals were positive at the age of 10 months.

In a survey carried out in Northern Norway, caseous lymphadenitis was found to occur in 19 out of 36 goat herds (Holstad 1986a). Animals which were at least 1 year of age were examined, and, in infected herds, superficial swellings were demonstrated in $26 \%$ of these. Altogether $81 \%$ and $84 \%$ of the animals were positive in the bacterial agglutination test (BAT) and the hemolysis inhibition test (HIT), respectively.

Information concerning the actual age at which infection occurs is necessary if effective immunoprophylactic measures against caseous lymphadenitis are to be introduced. The purpose of the present study was to investigate the relationship between the prevalence of animals with superficial swellings and antibodies against $\mathrm{C}$. pseudotuberculosis on the one hand, and age on the other.

\section{MATERIALS AND METHODS}

\section{Animals}

$\mathrm{Kids} / \mathrm{y} \mathrm{oung}$ a $\mathrm{nim}$ a l s. In 14 herds in which caseous lymphadenitis had existed for several years, serological and clinical examinations were undertaken of animals during their first year of life. Table 1 gives details of the time at which the examinations were carried out, and of the number of animals examined. In most herds (10), altogether 4 serological examinations were carried out. Clinical examinations were undertaken twice in 9 herds and once in 2 herds, while 3 herds were not examined clinically at all. Of the animals included, 160 individuals were examined serologically on each and every occasion. The kids were born during the period December-April. In all herds, the kids were placed in separate pens until put out to pasture in May-June. In some herds, the kids were placed in the same room as adult goats, while in other herds, some of the kids were placed in the same room as adult animals, and some in separate rooms. During the summer, the kids grazed together with adult goats in most herds. At the end of the grazing season (SeptemberOctober), they were housed for the winter, either in separate 
pens or in pens together with older animals. In 1 herd, however, the animals were placed in single stalls during the indoor season.

Corresponding examinations were carried out in a recently established herd. Table 4 shows when the examinations were carried out and the number of animals examined. In addition to kids raised on the farm, kids also originated from other infected and non-infected herds. Serological examinations of yearlings undertaken in March 1981 revealed 1 animal with a high positive titre in the bacterial agglutination test (BAT) while no animal had antibodies against the bacterium in the hemolysis inhibition test (HIT) (Holstad 1986a).

Adult animals. During the period March-May 1981, an investigation on the occurrence of caseous lymphadenitis was carried out in 36 goat herds (Holstad 1986a). Material from this investigation was used to study the prevalence of infection among. adult goats at different ages. Eight infected herds were selected. The disease had been present for several years in 7 of these herds, but only for 2 years in the remaining herd. Herd size varied from 40 to 97 animals, age distribution in each herd being similar. Only goats with known age were included in the present study. In all these herds, the goats were kept in pens.

\section{Serological examinations}

Blood samples were collected from each animal. Sera were prepared according to standard procedure and stored at $-20^{\circ} \mathrm{C}$. The samples were examined for antibodies to C.pseudotuberculosis using the bacterial agglutination test (BAT) and the hemolysis inhibition test (HIT). Titre values were expressed as $\log _{10}$ to the reciprocal value of the highest positive serum dilution in both tests, and positive titre (T) was stipulated as $\mathrm{T} \geq 2.1$ in BAT and as $\mathrm{T} \geq 0.6$ in HIT (Holstad 1986b).

\section{Clinical examinations}

The examinations were carried out in connection with collection of blood samples. The animals were inspected and palpated, and superficial swellings recorded. Swellings on the shoulder and chest were however, excluded as lesions at these sites were considered to be granulomas arising after vaccination against paratuberculosis. 


\section{Statistical analysis}

Statistical calculations were carried out using covariance analysis.

\section{RESULTS}

Kids / young animals from infected herds

Results of the serological and clinical examinations are shown in Tables 1, 2 and 3.

The prevalence of seropositive animals decreased from March/ April 1981 to May/June the same year, after which it again increased at subsequent examinations (Table 1). Most kids were positive in both BAT and HIT during the first months of life, while all animals of $3-4$ months of age were negative in both the tests (Table 2). At the age of 11-12 months the prevalence of positive animals was $50 \%$ in BAT and $30 \%$ in HIT (Table 2).

T a b l e 1. Results of serological and clinical examinations performed at different times on kids/young animals in herds with caseous lymphadenitis.

\begin{tabular}{|c|c|c|c|c|c|c|}
\hline \multirow{2}{*}{\multicolumn{2}{|c|}{$\begin{array}{l}\text { Time of } \\
\text { examination }\end{array}$}} & \multirow{2}{*}{$\begin{array}{l}\text { Number of } \\
\text { animals } \\
\text { examined } \\
\text { serologically/ } \\
\text { clinically }\end{array}$} & \multicolumn{3}{|c|}{$\begin{array}{l}\text { Percentage of animals } \\
\text { positive in }\end{array}$} & \multirow{2}{*}{$\begin{array}{l}\text { Percentage of } \\
\text { animals with } \\
- \text { superficial } \\
\text { swellings }\end{array}$} \\
\hline & & & BAT ${ }^{1}$ & HIT $^{2}$ & $\begin{array}{l}\text { BAT and/ } \\
\text { or HIT }\end{array}$ & \\
\hline March/April & 1981 & $282 /$ & 16 & 23 & 26 & - \\
\hline May/June & 1981 & $234 / 0$ & 6 & 5 & 6 & - \\
\hline October & 1981 & $235 / 207$ & 25 & 22 & 30 & 7 \\
\hline February & 1982 & $225 / 226$ & 63 & 56 & 68 & 29 \\
\hline
\end{tabular}

1 Bacterial agglutination test.

2 Hemolysis inhibition test.

The prevalence of animals with superficial swellings increased from $7 \%$ to $29 \%$ from October 1981 to February 1982 (Table 1). Out of 12 animals with such swellings in October 1981, 7 animals still had swellings in February 1982, and in 3 of these animals lesions were located at the same sites on both occasions. The prevalence of seropositive animals was higher in animals with superficial swellings than in animals without such lesions (Table 3). 
T a ble 2. Results of the bacterial agglutination test (BAT) and the hemolysis inhibition test (HIT) performed on sera from kids in herds with caseous lymphadenitis, grouped according to age (includes animals from Table 1 with known birth date).

\begin{tabular}{cccr}
\hline Age (months) & $\begin{array}{c}\text { Number of } \\
\text { animals } \\
\text { examined }\end{array}$ & \multicolumn{2}{c}{ Percentage of animals positive in } \\
\cline { 3 - 4 } & 7 & BAT & HIT \\
\hline $0-1$ & 115 & 71 & 100 \\
$1-2$ & 111 & 23 & 33 \\
$2-3$ & 39 & 0 & 10 \\
$3-4$ & 133 & 5 & 0 \\
$4-5$ & 29 & 3 & 3 \\
$5-6$ & 6 & 17 & 7 \\
$6-7$ & 12 & 22 & 33 \\
$7-8$ & 117 & 23 & 13 \\
$8-9$ & 58 & 16 & 21 \\
$9-10$ & 6 & 67 & 14 \\
$10-11$ & 30 & 50 & 67 \\
$11-12$ & 117 & 57 & 30 \\
$12-13$ & 41 & 63 & 53 \\
$13-14$ & & & 59 \\
\hline
\end{tabular}

T a b l e 3. Results of serological examinations performed on sera from kids/young animals with superficial swellings (a), and without superficial swellings (b), in herds with caseous lymphadenitis.

\begin{tabular}{lccccc}
\hline \multirow{2}{*}{$\begin{array}{l}\text { Time of } \\
\text { examination }\end{array}$} & Animals & \multicolumn{3}{c}{ Percentage of animals positive in } \\
\cline { 4 - 6 } & & BAT & HIT & BAT and/or HIT \\
\hline October & \multirow{2}{*}{1981} & a & 79 & 64 & 79 \\
& & b & 20 & 20 & 26 \\
February & \multirow{2}{*}{1982} & a & 89 & 78 & 92 \\
& & b & 53 & 46 & 58 \\
\hline
\end{tabular}

Kids / young animals from a recently established herd

Table 4 presents the results from the serological and clinical examinations.

Only $3(9 \%)$ animals were positive in HIT in March 1981, and 2 of these kids had been obtained from infected herds. In all examinations, the prevalence of seropositive animals was lower than in herds in which caseous lymphadenitis had existed for several years. 
T a b l e 4. Results of serological and clinical examinations performed at different times on kids/young animals in a newly established herd.

\begin{tabular}{|c|c|c|c|c|c|c|}
\hline \multirow[t]{2}{*}{$\begin{array}{l}\text { Time of } \\
\text { examination }\end{array}$} & & \multirow{2}{*}{$\begin{array}{l}\text { Number of } \\
\text { animals } \\
\text { examined } \\
\text { serologically/ } \\
\text { clinically } \\
\end{array}$} & \multicolumn{3}{|c|}{$\begin{array}{l}\text { Percentage of animals } \\
\text { positive in }\end{array}$} & \multirow{2}{*}{$\begin{array}{l}\text { Percentage of } \\
\text { animals with } \\
\text { - superficial } \\
\text { swellings }\end{array}$} \\
\hline & & & BAT & HIT: & $\begin{array}{l}\text { BAT and/ } \\
\text { or HIT }\end{array}$ & \\
\hline March & 1981 & $33 / 0$ & 0 & 9 & 9 & - \\
\hline June & 1981 & $49 / 0$ & 2 & 2 & 2 & - \\
\hline October & 1981 & $47 / 0$ & 4 & 2 & 4 & - \\
\hline February & 1982 & $47 / 47$ & 15 & 13 & 17 & 2 \\
\hline
\end{tabular}

Adult animals from infected herds

Mean titres in BAT and HIT and the percentage of positive animals in relation to age are shown in Table 5 . The titres in BAT and HIT increased from 1 to 6 years of age. The titres in both tests were significantly lower in yearlings than in older goats, $\mathrm{P}<0.005$.

T a b l e 5. Mean titres \pm standard deviation (s) for antibodies against C. pseudotuberculosis in the bacterial agglutination test (BAT) and the hemolysis inhibition test (HIT) for adult animals from 8 infected herds, and the percentage of positive animals in each test, according to age.

\begin{tabular}{rcccccc}
\hline \multirow{2}{*}{$\begin{array}{c}\text { Age } \\
\text { (year) }\end{array}$} & $\begin{array}{c}\text { Number of } \\
\text { animals } \\
\text { examined }\end{array}$ & $\begin{array}{c}\text { Titre } \\
\pm \mathrm{s}\end{array}$ & $\begin{array}{c}\text { Percentage } \\
\text { of positive } \\
\text { animals }\end{array}$ & & $\begin{array}{c}\text { Titre } \\
\pm \mathrm{s}\end{array}$ & $\begin{array}{c}\text { Percentage } \\
\text { of positive } \\
\text { animals }\end{array}$ \\
\cline { 3 - 4 } & & & & & & \\
1 & 151 & $2.45 \pm 1.27$ & 63 & & $0.77 \pm 0.78$ & 56 \\
2 & 99 & $3.11 \pm 1.22$ & 72 & & $1.42 \pm 0.73$ & 87 \\
3 & 72 & $3.41 \pm 1.33$ & 82 & & $1.58 \pm 0.62$ & 97 \\
4 & 61 & $3.54 \pm 1.31$ & 89 & & $1.43 \pm 0.72$ & 92 \\
5 & 39 & $3.79 \pm 1.23$ & 85 & & $1.68 \pm 0.66$ & 92 \\
6 & 38 & $4.19 \pm 1.12$ & 92 & & $1.82 \pm 0.59$ & 100 \\
$\geq 7$ & 43 & $3.77 \pm 1.09$ & 98 & $1.76 \pm 0.58$ & 98 \\
\hline
\end{tabular}

* $\log _{10}$ reciprocal value.

The prevalence of animals with superficial swellings is shown in Table 6. There were no significant differences between animals of different age as regards the prevalence of such lesions, $\mathrm{P}>0.05$. 
T a ble 6. Superficial swellings in adult animals from 8 infected herds, according to age.

\begin{tabular}{ccc}
\hline $\begin{array}{c}\text { Age } \\
\text { (year) }\end{array}$ & $\begin{array}{c}\text { Number of } \\
\text { animals } \\
\text { examined }\end{array}$ & $\begin{array}{c}\text { Percentage of animals with } \\
\text { superficial swellings }\end{array}$ \\
\hline 1 & 152 & 28 \\
2 & 100 & 30 \\
3 & 73 & 29 \\
4 & 61 & 18 \\
5 & 39 & 23 \\
6 & 39 & 33 \\
$\geq 7$ & 46 & 17 \\
\hline
\end{tabular}

\section{DISCUSSION}

The present study shows that most kids in infected herds possessed antibodies to C. pseudotuberculosis during their first months of life and that such antibodies were absent in animals at the age 3-4 months. The prevalence of seropositive animals then increased, especially up to 2 years of age. However, the titres in BAT and HIT increased until the animals were 6 years old. The prevalence of animals with superficial swellings increased up to one year of age and was from then on almost constant.

Both BAT and HIT were employed in the serological examinations in the present study. Burrell (1978) recommended the use of antitoxin tests in immunity surveys of sera from young lambs, because of a non-specific clumping factor in such sera. Holstad (unpublished) examined precolostral kid sera and found that several sera showed positive titres in BAT. In the present investigation, the youngest kid was 8 days old and only a few animals were less than 1 month of age. BAT was therefore also used in the present study for serological examination of kid sera.

Caseous lymphadenitis is not common in young kids. Ashfaq \& Campbell (1979) found superficial abscesses in 3 out of 1031 kids $0-3$ months of age. Antibodies against C. pseudotuberculosis are transferred from goats to their kids through colostrum (Burrell 1981, Lund et al. 1982, Anderson \& Nairn 1984). Lund et al. (1982) demonstrated no significant difference between the hemolysin titres in colostrum of the dams and in serum from their offspring at 3 days of age. In the same study, high correlation was found between titre values in sera taken from kids at 
3 days of age and at 4 and 7 weeks of age. In the present investigation, the proportion of seropositive animals decreased with age during the first months of life. This was due to the disappearance of maternal antibodies. Lund et al. (1982) calculated the halflife of maternal antihemolysins in kid serum to be $\mathbf{1 2}$ days and found that such antibodies could not be demonstrated in kid sera at the age of 12 weeks. Maternal antibodies are reported to protect the kids against caseous lymphadenitis. Anderson \& Nairn (1984) vaccinated goats with C. pseudotuberculosis toxoid. The offspring and offspring from non-immunized dams were challenged with the bacterium at the age of 1,6 and 11 weeks. Significantly more kids from non-immunized dams developed abscesses than did offspring from vaccinated goats after challenge at 1 and 6 weeks. Nairn et al. (1977) and Nairn (1981) report that $\mathrm{C}$. pseudotuberculosis antitoxin is of importance for protection against caseous lymphadenitis in sheep.

Moreover, environmental conditions may also be favourable with regard to reduction of the infection risk during the first months of life. In all infected herds, the kids were placed in separate pens until they were put out to grass. They therefore had little contact with adult animals during the first months of life. Blood samples were not collected from the kids during the grazing period. A few animals had superficial swellings when housed for the winter at the age of 8 months (mean age). At that time, $30 \%$ of the animals were seropositive in one or both tests. The animals had probably become infected during the summer through contact with adult goats.

The prevalence of animals with superficial swellings, and of seropositive animals, increased significantly from October in the one year to February in the next. Placing the animals together in pens probably resulted in rapid spread of infection. Animals may however, become infected several months before superficial swellings are obvious. Ashfaq \& Campbell (1980) found in the goat that the period elapsing between experimental infection and subsequent abscess formation in regional lymph nodes varied from 41 to 147 days.

In the newly established herd, only a few animals were seropositive in October the one year and in February the next. Animals obtained from herds with caseous lymphadenitis had probably been infected before entering the herd. The investigation indicates that the level of exposure to infection was lower in 
this herd than in herds in which the disease had existed for many years.

Most superficial swellings in goats are abscesses caused by C. pseudotuberculosis (Holstad 1986a). The present study shows that animals may have superficial swellings at the same body site for several months. The age of the lesions was however, not differentiated. The swellings could therefore have been developing in October and undergoing healing in February the next year. Moreover, the present study shows that the lesions can disappear and that superficial swellings can be demonstrated at other sites of the body after some months.

There was no difference between adult animals of different ages as regards the prevalence of superficial swellings.

The increase in titre value with age is probably a result of longstanding antigen stimulation. In the present study, the titre values increased until the goats were 6 years old. Lund (1980) found that titre values in BAT and HIT in naturally infected goats increased until the animals were 3 years old, and then decreased with age. The number of animals in the reported material was, however, significantly lower than in the present study and this may explain the discrepancy between the findings in the two investigations.

The present study indicates that any immunoprophylactic measures against caseous lymphadenitis in kids should be carried out before the kids reach the age of 4 months. The most suitable age at which kids should be vaccinated is, however, difficult to estimate. If maternal antibodies influence the effect of vaccination, immunoprophylactic measures should be carried out when the kids are between 3 and 4 months old.

\section{REFERENCES}

Anderson, V. M. \& M. E. Nairn: Role of maternal immunity in the prevention of caseous lymphadenitis in kids. In: Les maladies de la chevre. Colloque de l'INRA, Niort 1984. No. 28, 601-604.

Ashfaq, M. K. \& S. G. Campbell: A survey of caseous lymphadenitis and its etiology in goats in the United States. VM/SAC 1979, 74, 1161-1165.

Ashfaq, M. K. \& S. G. Campbell: Experimentally induced caseous lymphadenitis in goats. Amer. J. vet. Res. 1980, 41, 1789-1792.

Burrell, D. H.: Non-specific agglutination of Corynebacterium ovis by precolostral and young lamb sera. Res. Vet. Sci. 1978, 25, 373375 . 
Burrell, D. H.: Caseous lymphadenitis in goats. Aust. vet. J. 1981, 57, 105-110.

Holstad, G.: Corynebacterium pseudotuberculosis infection in goats II. Prevalence of caseous lymphadenitis in 36 goat herds in Northern Norway. Acta vet. scand. 1986a, 27, 584-595.

Holstad, G.: Corynebacterium pseudotuberculosis infection in goats I. Evaluation of two serological diagnostic tests. Acta vet. scand. 1986 b, 27, 575-583.

Lund, A., T. Almlid, T. Steine \& H. J. Larsen: Colostral transfer in the goat of antibodies against Corynebacterium pseudotuberculosis and the antibody status of kids during the first 10 months of life. Acta vet. scand. 1982, 23, 483-489.

Lund, A.: Kase $\varnothing$ s lymfadenitt hos geit. Serologiske unders $\varnothing$ kelser i en naturlig smittet besetning. (Caseous lymphadenitis in goat. Serologic investigations in a naturally infected herd). Dr. scient. Thesis. Norwegian College of Veterinary Medicine, Oslo 1980, 44 pp.

Nairn, M. E., J. P. Robertson \& N. C. McQuade: The control of caseous lymphadenitis in sheep by vaccination. Proc. 54th Ann. Conf. Aust. vet. Ass., Perth 1977, p. 159-161.

Nairn, $M$. E.: The control of caseous lymphadenitis in sheep. Refresher course in sheep. Proc. Postgraduate Committee on Veterinary Science. Sidney 1981, 58, 309-312.

\section{SAMMENDRAG}

Corynebacterium pseudotuberculosis infeksjon hos geit III. Relasjon til alder.

I 14 besetninger med kaseøs lymfadenitt og i 1 nyetablert besetning med kje innkjøpt fra ulike besetninger ble dyrene unders $\phi$ kt serologisk inntil 4 ganger til de var ca. ett år gamle. Kliniske unders $\emptyset$ kelser ble foretatt av disse dyrene 1 eller 2 ganger $\mathrm{i}$ de fleste besetningene i samme periode.

I 8 besetninger med kase $\varnothing$ s lymfadenitt ble det dessuten foretatt kliniske og serologiske unders $\varnothing$ kelser av voksne geiter av forskjellig alder. Aldersfordelingen til dyrene i disse besetningene var tilnærmet lik.

Sera ble unders $\varnothing \mathrm{kt}$ for antistoffer mot Corynebacterium pseudotuberculosis både ved bakterieagglutinasjonstest (BAT) og antihemolysintest (AHT).

Prevalensen av kje positive ved BAT og AHT avtok til null i løpet av de 4 første levemåneder. Ved 11-12 måneders alder var andelen positive dyr $\varnothing \mathrm{kt}$ til $50 \%$ ved BAT og $30 \%$ ved AHT. Prevalensen av dyr med overfladiske hevelser var $7 \%$ når dyrene var ca. 8 måneder gamle (gjennomsnittlig) ved innsetting om høsten. Ved ca. 1 års alder (gjennomsnittlig) hadde $29 \%$ av de unders $\varnothing$ kte dyrene slike lesjoner.

I den nyetablerte besetningern var få dyr serologisk positive ved 1 års alderen. 
Titeret ved BAT og AHT $\varnothing$ kte fra 1 til 6 års alder. Ett år gamle geiter hadde signifikant lavere titer ved begge testene enn eldre geiter, $\mathrm{P}<0,005$. Det var ingen signifikant forskjell $\mathrm{i}$ prevalensen av geiter med overfladiske hevelser $\mathrm{i}$ de ulike aldersgrupper fra og med 1 års alder.

(Received September 8, 1986).

Reprints may be requested from: Gudmund Holstad, the Department of Microbiology and Immunology, Norwegian College of Veterinary Medicine, Postbox 8146, Oslo Dep., Oslo 1, Norway. 